821.163.41.09 Симовић Љ. 821.133.1.09 Рабле Ф.

https://doi.org/10.18485/msc.2018.47.2.ch34

Слободан В. ВЛАДУШИЋ* Универзитет у Новом Саду Филозофски факултет
Оригинални научни рад

Примљен: 27. 9. 2017. Прихваћен: 27. 12. 2017.

\title{
СМИСАО КАРНЕВАЛИЗАЦИЈЕ КОД РАБЛЕА И ЉУБОМИРА СИМОВИЋА
}

\begin{abstract}
У раду се полази од Бахтинових анализа поетичких и филозофских везе између културе карневала и Раблеове књижевности. У светлу тог увида, анализира се и веза Симовићеве поезије и карневалске културе. Ослањајући се на рад Лидије Делић, у тексту се сугерише да у једном делу Симовићевог песничког опуса долази до преузимања поетичких црта карневалског наслеђа, али и до негирања њиховог карневалског смисла, односно карневалске слике света. Оригинални допринос овог рада јесте у томе што он указује на постојање другог, мање запаженог низа Симовићевих песама („Глад”, „Тањир пасуља” и неколико других песама) у којима је поетичка веза са карневалом шифрована. Ове песме, међутим, посредују основну црту карневалске слике света, а то је снижавање духовне на материјално-телесну сферу, при чему то снижавање у карневалу, али и у анализираним Симовићевим песмама, није проста негација старог света, већ истовремено и афирмација новог. Тиме се овај низ песама разликују од низа Симовићевих песама које истиче Лидија Делић, код којих поетичке црте карневала сугеришу модерно, нихилистичко искуство.

Кључне речи: карневал, слика света, поетика, нихилизам, гротеска.
\end{abstract}

Анализу смисла карневализације код Раблеа и Љубомира Симовића, започећемо, као што је и очекивано, поменом Бахтина и његовог капиталног дела Стваралаштво Франсоа Раблеа и народна култура средњег века и ренесансе у коме велики руски теоретичар испитује однос између карневалске културе и Раблеове књижевности. Бахтин показује да се овај однос испољава у две сфере: једна је поетичка, а друга филозофска. Дакле, Раблеова књижевност и култура карневала деле иста поетичка начела, те исти поглед на свет. Ове две сфере су, дакако, уско повезане.

Навешћемо само један пример који сведочи о тој повезаности: то је Бахтинова анализа гротескног реализма који је присутна у карневалу, али и код Раблеа. Основно својство гротескног реализма по Бахтину јесте „snižavanje,

*svladusic@ff.uns.ac.rs 
to jest prevođenje visokog, duhovnog, idealnog, apstraktnog na materijalno-telesni plan, plan zemlje i tela u njihovom neraskidivom jedinstvu" (Бахтин, 1978: 28). Моменат снижавања је дакле, важна поетичка црта гротескног реализма. Међутим, Бахтин ће врло брзо тој поетичкој црти придодати и увид у смисао који снижавање посредује: „Snižavanje kopa telu grob radi novog rađanja. Otuda ono nema samo uništavajuće značenje koje negira, nego i pozitivno značenje preporoda: ono je ambivalentno, ono istovremeno i negira i afirmiše" (Бахтин 1978: 29-30).

Бахтин истовремено указује на два момента гротескног реализма: први је његова поетичка константа, а то је снижавање духовног на ниво материјално-телесног; други моменат чини његова филозофска компонента, коју разоткрива увид да снижавање представља синтезу умирања и рађања, односно негације и афирмације.

На овом месту у Бахтиновој анализи Раблеове књижевности и културе карневала на сцену може да ступи историја. Наиме, поетичка црта гротескног реализма, а то је снижавање духовног на ниво материјално-телесног, може се понављати (а и понавља се) у даљем току књижевности, али то понављење не мора више да посредује исти филозофски смисао, односно исту слику света. Поетичко-формални аспекти културе карневала могу да преживе постепено исчезавање карневалске слике света. То сугерише и Бахтин, када примети да:

[...] književna parodija, kao i svaka parodija, snižava, ali to snižavanje ima čisto negativan karakter i lišeno je obnoviteljske ambivalentnosti. Zbog toga i parodija kao žanr i svako drugo snižavanje u uslovima novog vremena nisu mogli, naravno, da sačuvaju svoj raniji ogroman značaj (Бахтин 1978: 30).

Бахтинова примедба јасно указује да поетичко снижавање духовног на материјално-телесни ниво не мора нужно да припада култури карневала, односно да иста поетичка црта у промењеним друштвено-историјским околностима, не мора да посредује исти смисао, односно исту слику света. Одавде произилази да је Рабле за Бахтина карневалски романописац не само зато што користи поетичке црте културе карневала, или пак карневалске, уличне говорне жанрове, већ и зато што код овог писца поменуте поетиче црте и жанрови посредују карневалску слику света која је оличена у негацији старог и афирмацији новог света.

Проширујући анализу веза између Раблеове књижевности и културе карневала са формално-поетичког аспекта на филозофски аспект, Бахтин је у стању да веома проницљиво реконструише трансформацију гротеске у каснијој историји књижевности. Он може да укаже на разлике између карневалског, гротескног реализма са једне стране, те романтичарске и модерне гротеске са друге стране. Бахтин непрекидно има у виду да се слика света коју посредује гротеска мења: на пример, у романтизму, гротеска упућује на став индивидуе према свету, те тако губи онај општенародни карактер који је имала у карневалу. Модерна гротеска опет упућује на то да је некада присни свет сада постао стран, те да та страност борави сада и у самом субјекту; таква 
туробна, модерна гротеска, сасвим је другачија од карневалске гротеске која установљава могућност другог (а не страног) света, не познаје индивидуу издвојену из народа/карневала, док коначности смрти супротставља веселу слику света који нестаје и обнавља се у исто време.

Шта нам, дакле, Бахтинова истраживања поручују у методолошком смислу? Ево једног могућег одговора: она нам сугерише да приликом анализе веза између модерне књижевности и карневалске културе није довољно анализирати само њихове поетичко-формалне сличности, већ истовремено треба обратити пажњу и на слику света коју у модерном књижевном делу посредују поетичке црте карактеристичне за поетику карневала. Отуда, када кажемо карневализам, треба да обратимо пажњу и на поетичке црте културе карневала - али и на слику света које оне посредују.

На овај начин, неприметно, ступамо и у поље књижевних вредности: уколико се у модерном књижевном делу гротеска појављује само у полемичком контексту према гротесци у карневалу, тачније, уколико слика света коју посредује модерна гротеска тек негира слику света карневалске гротеске, онда је упутно поставити питање о вредности таквог модерног књижевног дела. Наиме, модерно књижевно дело би тада било само документ времена у коме настаје, а не више и покушај да се властита епоха уоквири, да се сагледа из једне спољне позиције коју, парадоксално, нуди управо другачија (карневалска) гротеска која посредује другачију слику света од модерне. То наравно, не значи да би једноставно преузимање слике света коју посредује карневалски, гротескни реализам, само по себи, подигло вредност одређеног модерног књижевног дела - то би био пуки анахронизам - али значи да вредност тог дела зависи од комплексности односа према карневалском наслеђу, а не тек од једноставне и догматске негације тог наслеђа.

Ова прелиминарна теоријска разматрања неопходна су нам за контекстуализацију односа између карневализма у поезији Љубомира Симовића и Раблеовог књижевног дела, које, као што је то Бахтин убедљиво показао, сумира карневалску културу и у сфери поетике и у сфери смисла, односно слике света коју карневал посредује.

Разуме се, то да постоји веза између Симовићеве поезије и културе карневала није никакав нов и оригиналан увид. О томе су већ писали књижевни критичари. За ову прилику издвојили бисмо рад Лидије Делић „Наслеђе карневалске културе у поезији Љубомира Симовића", који већ својим насловом недвосмислено упућује на ову везу. У закључку рада, ауторка подвлачи комплексност односа Симовићеве поезије и карневалске културе: најпре, она сасвим тачно закључује да се „цела једна линија жанровски и тематски хетерогеног песништва Љубомира Симовића ослања [...] на традицију везану за карневал и карневалску културу” (Делић 2009: 486), да би затим нагласила и елемент разлике:

Међутим, код Симовића се јавља и битан отклон од значење које слике гозби, обиља хране и смрти имају у празничном, карневалском контексту. Наиме, у Симовићевој поезији је - као у модерном песништву и модерној књижевности уопште - дошло до раздвајања карневалске форме од ритуалног карневалског значења (Делић 2009: 487). 
Запажања Лидије Делић о односу Симовићеве поезије и карневалског наслеђа су тачна и треба их узети у обзир приликом даљих истраживања поезије овог песника. Међутим, постоји и једна нит Симовићеве поезије која не тежи толико да негира смисао карневала, колико да, на неки начин, модернизује то наслеђе, како би се оно могло појавити и у другачијем епохалном контексту, а да притом не буде рецепирано као анахроно. И сама Лидија Делић је на том трагу када је у последњем пасусу поменутог рада извела следећи закључак: „Симовићу, међутим, није остао стран ни хуморни, весели, ругалачки поглед на све, што његову поезију, местимично, не само формално већ и по духу и смислу чини блиском карневалској култури и њеном ведром оптимизму” (Делић 2009: 487).

Овај врло инспиративан навод Лидије Делић настаје на основу кратке анализе „Ругалица о вину”, те „Молитве светом Нестору који је убио алу а из ње постали мишеви гуштери змије и друга гамад”. Ауторка овде указује на, пре свега, пародични аспект обеју песама које се подсмевају и ругају официјелној (српској) средњовековној и хришћанској култури.

Међутим, по нашем мишљењу, ова црта Симовићевог певања је знатно развијенија него што се то чини на први поглед и не може да се сведе на две поменуте песме. Сматрамо да код Симовића постоји једна група песама која шифровано упућује на карневалско наслеђе, односно на карневалску слику света. То наслеђе није видљиво на први поглед, али се његово присуство испољава у току процеса интерпретације песме. Издвојили бисмо у том смислу песме „Глад” и „Тањир пасуља”. Песму „Глад” ћемо цитирати у целости:

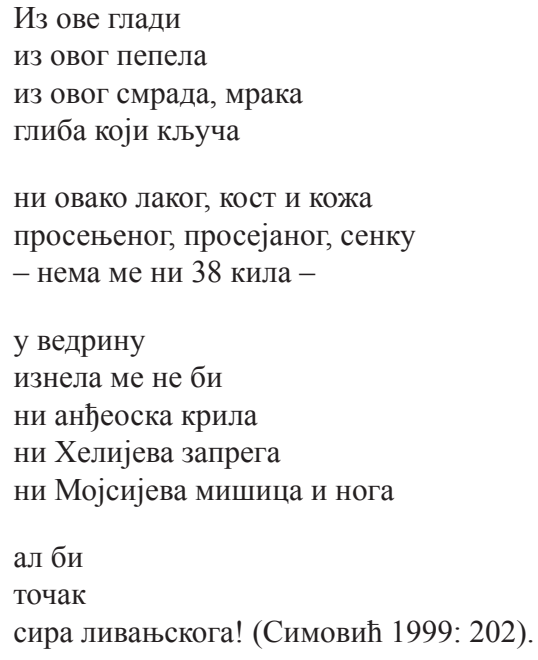

У овој песми се може добро видети момент шифровања карневалског наслеђа у модерној поезији. То наслеђе је прикривено, али је присутно на нивоу слике света. На ову прикривеност карневалског искуства упућује, пре свега, ситуација глади. Мотив глади одудара од карневалске слике света, о чему сведоче не само обилни низови пића и хране код Раблеа већ и низови 
хране у оним Симовићевим песмама у којима су критичари већ препознали везу са карневалском културом; такве су песме „Гозба” и „Велики риболов”. Дешифровати мотив глади у овој песми значи видети да глад овде не посредује аскетизам који своје исходиште има у хришћанској слици света. Глад овде није пост. Глад у цитираној Симовићевој песми има, заправо, двоструки карактер: метафоре „пепела”, „смрада”, „мрака”, „глиба”, креирају симболичко-духовни карактер глади - она постаје стање духа, стање свести, а не тела. Међутим, та духовно-симболича црта иронизована је и употпуњена навођењем егзактне тежине лирског субјекта - 38 кила - чиме се мотив глади материјализује.

Одлучујући моменат за разумевања ове песме је херменеутичко откриће да се ова двострука глад (духовна и материјална) не може задовољити на духовно-апстрактном нивоу, који је сугерисан симболима хришћанског, античког и јудејског мита: крилима анђела, Хелијевом запрегом, или Мојсијевим мишицама и ногом. Она се може задовољити само материјално-телесним принципом, који подржава мотив ливањског сира. Опозиција између афирмисаног материјално-телесног принципа и негираног духовно-апстрактног принципа сугерисана је количином хране (точак сира) као и знаком узвика на крају песме, који одудара од стања духовне скрушености, скрушености молитве, на пример. Напротив, рекли бисмо да тај узвик сугерише одушевљеност тела које се нахранило и које тако нахрањено оживљава. Завршетак ове песме зато дочарава управо карневалску слику света, у коме се негирање духовне хране (мит), па тако и духовности, путем мотива материјалне хране (точак ливањског сира) истовремено преображава у афирмисање новог живота, који настаје када се у изгладнело тело унесе храна.

Овде се тумачење ове помало занемарене Симовићеве песме, наравно, не завршава. Критичар склон деконструкцији могао би да приговори како у овој песми тај ливањски сир недостаје, односно како те материјалне хране заправо нема. Она постоји само као нада. Тада би сир који се дозива, али кога нема, постао симбол невидљивог, па би тако из сфере материјалности прешао у сферу онога што негира, а то је оно духовно, невидљиво. Ова песма би тада постала још један пример демановске алегорије нечитљивости. Међутим, чак и тада би ова песма садржала карневалску слику света као једну од могућности читања: она негира духовно-апстрактни принцип у име материјално-телесног, истовремено афирмишући свет који настаје из те негације - у тој могућности би била ситуирана карневалска слика света. Супротно, невидљивост сира, његова идеалност, означавала би тада (нужну) модерну дистанцу од карневалске слике света, која тај свет не негира колико га „пакује" тако да може да се појави у модерном времену.

Анализираној песми „Глад” сродна је песма „Тањир пасуља”, која се завршава стиховима:

„Погнуте главе почињем да једем једем озбиљно једем полако 


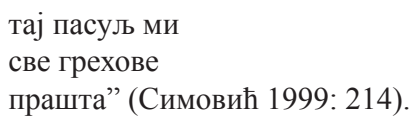

Цитирана последња строфа песме представља поенту која се може разумети као још једна варијација канрневалске афирмације материјално-телесног принципа у односу на духовни: овде се гестови и термини духовности (погнута глава, праштање грехова) перветирају тако да подржавају материјално-телесни феномен хране која се уноси у стомак: та храна је пасуљ, и пасуљ је тај који опрашта грехе, а не Бог. И овде је присутно шифровање карневалског искуства: обилни низови хране су замењени једним тањиром пасуља, што свакако, донекле прикрива карневалско исходиште ове песме. Међутим, то исходиште се може реконструисати херменеутичким увидом који потврђује да се у песми испољава карневалско снижавање духовног на раван материјално-телесног, уз помоћ мотива хране: грехове не прашта неки духовни ентитет, већ нешто материјално - храна. Јасно, праштање грехова је увод у нови живот, па се тако и у овој песми негирање духовног момента материјалном храном (пасуљем) истовремено преображава у афирмацију новог живота.

На сличан механизам снижавања духовног у име материјално-телесног наилазимо и у песми „Ручак у кујни за сезонске раднике на пољопривредном добру у Турици". На први поглед, топоним песме (Турица), као и простор одвијања песме (,кујна” на пољопривредном добру) упућују тумача на групу Симовићевих песама у којима је истакнут веристички моменат. Критика је ову веристичку компоненту Симовићевог певања већ уочила (в. Ђорђевић 1996). Међутим, пажљивије читање конкретне песме указало би и на присуство карневалског механизма описаног у претходно цитираним песмама: духовно се овде и снижава на ниво материјално-телесног путем хране. Поменути механизам проналазимо и у песмама „Преображење” и „Бог олује у лугарници”, које описују силазак богова на земљу што може схваћено у контексту поступка инверзије (Микић 1996: 28), али и као особен тип снижавања духовног на ниво материјално-телесног уз помоћ мотива хране.

Поменуте песме потврђују да у Симовићевом опусу постоји нит песама које поседују шифровано карневалско наслеђе оличено, пре свега, у карневалској слици света, која се донекле полемички наслања на поетичке црте карневалске културе, односно препознатљиве карневалске слике, као што су низови хране и пића.

На овом месту треба обратити пажњу на битну полемичку карактеристику наведених песама у односу на добро познате Симовићеве песме „Гозба” и „Велики риболов”, у којима се присутна врло јасна полемика са карневалском сликом света. Наиме, док у потоњим песмама мотив хране сугерише пре свега модерно, нихилистичко искуство, односно искуство апсурда, у песмама као што су „Глад”, „Тањир пасуља”, „Ручак у кујни за сезонске раднике на пољопривредном добру у Турици”, „Преображење” храна губи своју модерну, нихилистичку ауру. Сасвим супротно, снижавање духовног путем хране на материјално-телесно, овде сугерише рађање новог живота или одржање 
живота, што је управо супротно нихилистичким исходима песама „Гозба” и „Велики риболов”: у првој „,- поједене звери једу нас изнутра” (Симовић, 1999: 18), док се у другој „не зна ко ће кога вечерати на жару” (Симовић, 1999б: 77). Као што видимо, у обе песме је живот лирског субјекта угрожен, што је знак продора нихилистичке свести у карневалску слику света, у коме су низови хране, сасвим супротно, сугерисали радост и ведрину живота.

Такође, треба обратити пажњу и на феномен шифрованог карневалског наслеђа. Јасно је да у модерном свету непосредна тематизација карневалске слике света уз помоћ поетичких црта карневала или карактеристичних карневалских слика више није могућа. Да би се карневалска слика света сугерисала, да би се карневалско искуство амбивалентног снижавања духовног на ниво телесно-материјалног испољило, потребно је то искуство на неки начин шифровати. Песме којима смо посветили највише простора у овом раду нису, дакле, тек копија поетичко-филозофског склопа карневалске књижевности. То значи да се и оне, у неку руку, полемички односе према том комплексу. Међутим, та полемичност је другачије врсте од оне коју можемо наћи у песмама попут „Великог риболова” и „Гозбе”, у којима се јасно изражене тематске и поетичке црте карневала (низови хране и топос изокренутог света) подешавају тако да посредују слику света модерне, а не карневалске гротеске.

У Симовићевој поезији наилазимо, дакле, на два типа односа према карневалској слици света: један је афирмативан, други је негаторски. Модерном читалачком сензибилитету свакако је ближи онај модерни, негаторски тип односа, јер карневалско исходиште песме ту није шифровано, а њен филозофски исход одговара нихилистичком хоризонту епохе. Међутим, као што смо видели на примерима песама „Глад” и „Тањир пасуља” (као и осталим из тог круга, које смо само поменули), код Симовића постоји и афирмативан однос према карневалској слици света.

Ова комплексност свакако говори у прилог вредности Симовићевог опуса: песник се очигледно није задовољио само (модерном) афирмацијом материјалног-телесне сфере света, која у модерним временима упућује на нихилистичко искуство света. Ту неминовност, сасвим хуманистички, Симовић је покушао да релативизује и другачијим типом песама у коме шифровано карневалско искуство упућује на могућност афирмације материјално-телесног принципа које се неће завршити у нихилизму.

Није нужно бирати између карневалско-традиционалне и модерно-нихилистичке сфере Симовићеве поезије: важније је разумети зашто се оне појављују упоредо, зашто Симовић настоји да у свом опусу заузме, истовремено, различите позиције у погледу односа према духовном и материјалнотелесном. У питању је можда особен начин на који Симовић изражава властиту склоност ка тоталности, коју проналазимо како у Броховим поетичким разматрањима модерне књижевностиํㅜ, тако и у зачецима социологија знања

${ }^{1}$ У том смислу треба читати Брохово схватање уметности, па тако и књижевности, којој је „posebnom sudbinskom konstelacijom [...] dodeljen zadatak da bude žižom anonimnih sila epohe, da 
код Карла Манхајма. ${ }^{2}$ Парадоксално, управо та воља за тоталним повезује средњовековни карневал који обузима цео град и модерну књижевност која тежи сагледавању целине епохе, ма колико јој је посао отежан услед осећања затамњености смисла света.

У тренутку када ова воља за тоталним буде напуштена у име постмодерног увида (или вере) у немогућност њеног остварења, имплицитно се отвара могућност заснивања партикуларних књижевности које се темеље било на жанровским посебностима текста било на идентитетским посебностима аутора̂ текстова. Жеља за тоталитетом и афирмисање ове жеље тада уступа место идеолошком и економском радикализму, који нужно оставља траг и на самој књижевности.

\section{ЛИТЕРАТУРА}

Бахтин 1978: M. Bahtin, Stvaralaštvo Fransoa Rablea i narodna kultura srednjeg veka i renesanse, Beograd: Nolit.

Бpox 1979: H. Broh, Pesništvo i saznanje, Niš: Gradina.

Делић, 2009: Л. Делић, Наслеђе карневалске културе у поезији Љубомира Симовића, ЛМС, год. 185, књ. 484, св. 4, 478-487.

Ђорђевић 1996: Ч. Ђорђевић, Веристички поступак у песништву Љубомира

Симовића, Повеља, бр. 1, 36-41.

Манхајм 1968: K. Manhajm, Ideologija i utopija, Beograd: Nolit.

Микић 1996: Р. Микић, Инверзија и лирски опис, Повеља, бр. 1, 18-28.

Симовић 1999: Љ. Симовић, Изабране песме I, Београд: Стубови културе.

Симовић 1999б: Љ. Симовић, Изабране песме II, Београд: Стубови културе.

Slobodan V. Vladušić

THE SENSE OF CARNEVALIZATION IN RABELAIS AND LJUBOMIR SIMOVIĆ

(Summary)

The paper opens with Bakhtin's analyses of poetic and philosophical links between the culture of the carnival and Rabelais's literature. In the light on such an insight, we also analyze the connection between Simović's poetry and carnivalesque culture. Referring to Lidija Delić's text, the paper sug-

ih okuplja u sebi, kao da je sama za sebe duh vremena, da unosi red u njihov haos i da ih na taj način podređuje vlastitim ciljevima" (Бpox 1972: 149).

${ }^{2}$ Манхајм у свом делу Идеологија и утопија овако афирмише вољу за тоталношћу: „Totalnost stoga, u našem smislu, ne znači sagledavanje koje se može pripisati samo nekom božanskom oku, sagledavanje koje je neposredno i jednom zauvek važeće, niti znači relativno u sebe zatvorenu sliku koja teži ka potpunom miru. Totalnost znači usmerenost ka celini, usmerenost koja obuhvata u sebi partikularne načine gledanja i neprestano probija njihove granice; ova usmerenost se korak po korak sve više širi u prirodnom procesu saznanja, a za cilj ima ne neku dokrajčenost koja bi bezvremeno važila, nego maksimalno moguće proširenje vidnog polja” (Манхајм 1968: 86). 
gests that one segment of Simović's poetic opus assumes poetical traits of the carnivalesque tradition, but as well the negation of the essence of the carnival, that is, the carnivalesque image of the world. The originality of this paper resides in the pointing out of the second, less known sequence of Simović's poems ("Glad" ["Hunger"], "Tanjir Pasulja" ["Bean Plate"], and several other poems) in which the poetic relation to the carnival is coded. However, these poems possess basic traits of a carnivalesque image of the world, which is a reduction of the spiritual sphere down to the material-corporal sphere, whilst the reduction in the carnival, and in Simović's poems we analyze, is not a mere negation of the old world, but it simultaneously presents an affirmation of the novelty. This is what differentiates this sequence of poems from the other Simović's sequence as noted by Lidija Delić, in which the poetic traits of the carnivalesque suggest a modern, nihilist experience. 